Journal of Social and Development Sciences

Vol. 4, No. 7, pp. 339-348, July 2013 (ISSN 2221-1152)

\title{
The Effectiveness of Micro-Finance Institutions in Alleviating Poverty: The Case of Bangladesh's Grameen Bank and BRAC
}

\author{
${ }^{1}$ Naziruddin Abdullah*, ${ }^{2} \mathrm{Md}$ Shah Jalal Uddin \\ ${ }^{1}$ UniKL Business School (UBiS), Malaysia \\ ${ }^{2}$ International Islamic University Malaysia, Malaysia \\ *naziruddin@bis.unikl.edu.my
}

\begin{abstract}
Microcredit is the most effective and successful way to let the poor having access to credit. Research to study its impact on alleviating poverty among the poor is numerous. However, unlike others, our study examines the effectiveness of Grameen Bank and BRAC, the two major micro-financers in alleviating poverty among the most disadvantaged people in Bangladesh. Hitherto, a study of this nature in which two Bangladesh's micro-financers operating in four districts are surveyed and appraised side by side is hardly at one's disposal. As such, this study can be considered as pioneering in its attempt. Our study has revealed the followings: (i) the poor are the direct beneficiary of the existing micro-finance institutions in Bangladesh. Nevertheless, some of them, especially those who have accounts in both banks, are having problem to repay the loans. Therefore, a mechanism has to be devised to limit each person to enjoy one loan at a time. In addition, a high percentage of the poor in Bangladesh is looking forward to making loans from interest-free banks; and, (ii) the services rendered by both micro-financers to the poor are still no better than the conventional banks. In fact, more than 50.0 per cent of the respondents have shown their dissatisfaction with the services extended to them. To address this problem, it is highly recommended for both micro financers to improve their services by way of making it mandatory for their staff to undergo relevant training programs.
\end{abstract}

Keywords: Micro-finance Institutions, Poverty, Grameen Bank, BRAC, Collateral

\section{Introduction}

The term poverty is known to all. Briefly, it is a state when people are unable to fulfill their basic needs. Several measures have been taken by the policy makers to alleviate poverty, among which micro-financing was one. The idea of microfinance is very much related with the concept that the poor should have the chance to change their economic plight by getting access to loan from financial institutions in a less expensive way. Muhammad Yunus, the founder of Grameen Bank and the father of micro-finance, found the blind spot of conventional banking system where they deprived the poor from getting access to loan without collateral. In Asia, India and Bangladesh are dominating the microfinance institutions where seven out 10 borrowers are either from India or Bangladesh, and $91 \%$ of funds disbursed for loan are used for microenterprises ${ }^{1}$. Microfinance institutions in Bangladesh are creating a new path to get rid of poverty in a large scale. At the end of 2010, about 205,314,502 clients were served by 3,652 microfinance institutions. Among them 137, 547,441 were the poorest when they took loan and $82.3 \%$ were women (Maes and Reed 2012). According to a report by Microcredit Summit Campaign, about two million Bangladeshi households involved in microfinance which include nearly 10 million family members, who survived on $\$ 1.25$ a day threshold between 1990 and 2008. In Bangladesh, for per hundred thousand adults there are two microfinance institutions compare to five commercial banks. However, almost 343 people out of per thousand are having account in microfinance institutions compare to 42 people having it in commercial banks 2 .

\section{Bangladesh's Micro-Finance Institutions: A Glimpse}

Grameen Bank: "Poor people are bonsai people. There is nothing wrong with their seeds. Only society never gave them a base to grow on". This was the phrase popularly associated with Muhammad Yunus (the 2006

\footnotetext{
${ }^{1}$ Microfinance Information Exchange, 2011 Asia Regional Snapshot

${ }^{2}$ http://www.cgap.org/p/site/c/template.rc/1.11.142557/
} 
Noble Laureate), the founder of Grameen Bank. From the embryonic stage until the decade of 1980s, Yunus had given poverty reduction in Bangladesh, one of the poorest countries in the world, a new lifeline. Specifically, he provides a small amount of loan to a group of poor women with a strong conscience that he can change their life from the current miserable situation to a better one. As expected, by so doing, he proves that all conventional dogmas were wrong for depriving the poor from getting access to loans. A testimony of this success is that nowadays the Grameen method of financing the poor is being used extensively in 58 countries, including the USA, Canada and France ${ }^{3}$, among others. Historically, Grameen Bank, the best known microfinance institution in the world, started in 1976 in the form of a closely monitored project in the village of Jobra. The success of this project has led the founder to establish an independent bank regulated by the government in 1983 and named it "Grameen Bank". The bank later became the largest micro-credit institution in Bangladesh. To give an example of how it operates, in the case of ownership, 95\% of the total equity was owned by the poor borrowers, while in terms of loan repayments it recorded the highest with 96.67\% loan recovery rate. Although at the beginning of its establishment, Grameen Bank, to a large extent, depended on grant money to run the operation, as of 1998 it largely depended on members' deposits as a source of finance. In 2011, the borrowers of the Grameen Bank were 8.35 million with loan disbursements of about USD1105 million. Currently, Grameen Bank has 2,565 branches, which covered 81,379 villages in Bangladesh.

BRAC: Meanwhile, in 1971, another social worker, Sir FazleHasan Abed, established BRAC. The aim was to rehabilitate refugees returning to Bangladesh from India after the 1971 devastating war in Sylhet, a district in the northeast of the country. Initially, the primary objective of this organization was to alleviate poverty and empowering the poor. Now, it has become the world largest development organization, well known for its multidimensional approaches. As far as BRAC credit extensions are concerned, microcredit is one of the oldest and also the largest programs undertaken by BRAC where it started as early as 1974. The present form of program, which was introduced in 1990, is known as the Rural Credit Project (RCP), an important component of BRAC's larger Rural Development Project (RDP). The objective of RDP is four fold: (1) to generate employment opportunity for both males and females; (2) to mobilize under- and un-utilized resources; (3) to assist in diffusing appropriate technology in the rural areas; and, (4) to promote better health care. According to MIX report (2011) BRAC has five million active borrowers with gross loan portfolio of USD646.1 million. BRAC provides two kinds of loan to the poor in Bangladesh. The first type is microloans known as 'Dabi'. It is given to women and it ranges from USD50-700. The loans were largely used for small operations in poultry, livestock, fruit and vegetable cultivation, and handicrafts or rural trade. The second type is microenterprise loans, known as 'Progoti', and is given to male and female who failed to secure loan from the conventional banking system. The loans support and help expand their existing small enterprises. For this type of loan the amount extended ranges from USD700 to USD10000 and the main sectors getting the loans are shops and small-scale manufacturing activities. Although the amount of loan extended by BRAC set off from BDT4000, more than half of the borrowers (52.5\%) prefer taking it within the BDT4001-10,000 range ${ }^{4}$. Having briefly introduced Grameen Bank and BRAC, and its respective activities, one common denominator emerges from both of the founders, Muhammad Yunus and Sir FazleHasan Abed. That is to say, both of them had a very decent life outside Bangladesh but decided to settle down in their home country to serve the poor. While Muhammad Yunus was an Assistant Professor of Economics in Middle Tennessee State University in the USA, Sir FazleHasan Abed was a senior corporate executive at Shell Oil.

\section{Literature Review}

Microcredit is the most effective and successful way to let the poor having access to credit for the last three decades, and indeed for this reason it is world-widely acknowledged. Research to study the popularly known "banking for the poor" impact on alleviating poverty among the poor is numerous. The major attributes of this banking system is that it provides small amount loan to the poor with shorter time period (usually one year), and without collateral. Specifically, in the case of Grameen Bank it is demonstrated that "Microcredit programs extend small loans to the very poor people for self-employment projects that generate income, allowing them to care for themselves and their families" (Grameen Bank website). The important

${ }^{3}$ http://www.grameen-info.org/index.php?option=com_content\&task=view\&id=329\&Itemid=363

${ }^{4}$ MRA-MIS database 2010 
contribution of microfinance has not been confined to Asian region, particularly Indo-Pak sub-continent. In fact, the operation has infiltrated into Latin American region especially Bolivia. The presence of microfinance in these two regions; Grameen Bank in Bangladesh and Banco Sol in Bolivia, is remarkable as manifested from the market shares in terms of credit extensions to the poor. It is a well-known fact that these two banks are the giants in microcredit in these two regions. In general, in order to evaluate the performance of microfinance institutions, three aspects are taken into consideration, each one is represented by one school of thoughts(Hulme 2000). Firstly, the school which argues that there is a positive social and economic impacts of microfinance in helping poor people (Hossain 1988), (Schuler \& Hashemi, 1997) and (Shahidur 1998). Secondly, the school that describes the negative impacts of microfinance may have on the poor (Adams and Von Pischke 1992), (Buckley 1997). Lastly, the group stands in the middle. That is, it is indifferent with regard to the impacts of microfinance on elevating the poor people income.

In another study, Olivares-Polanco (2005) makes a different categorization of evaluating the impact of microfinance where he bifurcate it into groups known as scholars and practitioner. While the first group, also known as welfarist, believed that microfinance should focus on reaching the poorest and help alleviate both the material and non-material aspects of poverty, the second group, the so-called operationist, concentrates more on financial operations of providing services to a large number of poor people. Another issue that is closely related to microfinance is how effective it has been used as a tool to combat poverty. According to Harper (2003), "in most developing countries, policies for rural financial development have been based on three erroneous beliefs concerning their target groups: One, rural micro entrepreneurs are unable to recognize themselves; two, they are too poor to save; and, three, they need cheap credit for their incomegenerating activities or small enterprises. Unlike other modes of financing extended by the conventional banking system where the mechanism used is somewhat to the disadvantage of the poor, microfinance uses a simple mechanism which gives the poor direct access to credit to finance their productive activities with minimal constraint (Montgomery and Weiss 2004). From the early 1980s Grameen Bank and BRAC have been working with the lower segments of the people in Bangladesh. It has been shown that Grameen Bank had helped poor people to enhance their income in sustainable ways. Morduch (1999) indicated that households served by Grameen bank have higher consumption rate and providing school enrollment to their children as compare to households in the bottom income group who are not served by Grameen Bank.

Another aspect of loan facilities that has been the subject of in-depth study is micro-finance's loan extension to women. In the case of Grameen Bank and BRAC, women empowerment through income elevating program has shown a very promising result. A joint research project by Bangladesh Institute of Development and the World Bank has found that microfinance helps women to gain assets on their own, which in turn enable them to exercise the power of decision making in household matters. To give but one example, for this purpose Grameen Bank gives $\$ 27$ loan to the women (Yunus 2003). Having said this, the main objective of this study is to examine the effectiveness of the above-mentioned two micro-financers in alleviating poverty among the most disadvantaged people dwelling in one of the poorest countries in the world; Bangladesh. To this end, four districts have been chosen where both Grameen Bank and BRAC have engaged with the poor by way of extending loans to them. To the best of our knowledge, a study of this nature in which two Bangladesh's micro-financers operating in four districts are surveyed and appraised is hardly at one's disposal. As such, this study can be considered as pioneering in its attempt.

\section{Methodology}

This study examines the effectiveness of BRAC and Grameen Bank, the two micro-financers operating in Bangladesh, in alleviating poverty among their participants. Our sample consists of participants of the microfinance programs in four districts, namely Bagerhat, Jessore, Jhenaidah and Satkhira. The reason for choosing the four districts is that it is the place where most disadvantaged poor people in Bangladesh dwelled and made a living. Initially, the questionnaires were distributed to 467 respondents. However, due to incompleteness of some of the questionnaires, 47 of them had to be discarded. As a result, we were left with 420 questionnaires from which our analysis is based. Out of the 420 respondents, we classified them into three groups: who have account with BRAC (135 participants) ${ }^{5}$; who have account with Grameen Bank (150

\footnotetext{
${ }^{5}$ In this study, the terms respondent and participant will be used interchangeably.
} 
participants); and, who have account with both BRAC and Grameen Bank (135 participants). The participants are chosen randomly from different centers/villages. All participants in this survey are ethnic Bengali and a set of questionnaires in Bengali language was prepared and distributed to them ${ }^{6}$. A wide range of topics are covered in the questionnaire, which include, among others, respondents' socio-economic background, income-expenditure-savings, assets, opinion on loan amount, general information about other banking products and poverty reduction scheme. Appendix 1 reports the demographic features of the study's respondents. To give a snapshot, first, the majority of BRAC and Grameen bank's participants in all areas are women. Of the total 420 respondents, 75.7 percent (318 respondents) are women, and 24.3 percent (102) are men. Second, the respondents constitute 53.1 percent (223) and 23.1 percent (97), respectively, from the Jessore and Jhenaidaho districts, while both Satkhira and Bagerhat have 11.9 percent (50) of the sample. Third, Muslims consist of 79.8 percent of the respondents, while the remaining 20.2 percent is shared between Hindu (18.6 percent) and Christian (1.6 percent).

Model and Data Analysis Techniques: This study uses several methods to analyze the results. First, we employ the descriptive measures such as frequencies, proportions and means as it provides us the general summary of the findings. The results are also used to compare the respondents' opinion pertaining to BRAC and Grameen Bank banking services such as: reasons for opening bank account with BRAC or Grameen or both; and, their opinions on problems they faced when dealing with the two micro financing institutions. Second, for a more in-depth analysis, independent sample T-tests is used to compare the means of the same variables between BRAC and Grameen bank. The variables that we choose here are divided into two categories. One, it is related to how clients benefitted from the services extended by the bank staff. This includes the presence of bank staff, responsiveness of bank staff, courtesy and friendliness of bank staff, helpfulness and knowledge of bank staff and how bank staff monitors the business. Two, we asked how banks' clients benefitted from the loan structure such as easy access to loan, modes of doing transaction with bank and other services offered by bank. Finally, we use the typical five-level Likert scale ranking (1= very poor, $2=$ poor, $3=$ neutral, $4=$ good and $5=$ very good) to examine and determine the variables that are related to the services extended by the banks' management and the performance of the two groups of our respondents; one belonged to BRAC, and another to Grameen Bank.

\section{Empirical Findings}

In general, all respondents are literate where 59 percent of them underwent primary school education until Grade Eight. Surprisingly, 20.4 percent have a secondary school certificate (SSC), 0.5 percent has a higher secondary school certificate (HSC) ${ }^{7}$, and 20 percent have a vocational or diploma degree. Majority (96.7 percent) of the respondents is married; the remainder (3.3 percent) is either unmarried, divorced or widow. Meanwhile, more than 50 percent of the female respondents are homemakers (60.9 percent) and others are tailors (11.5 percent), business owners ( 9.5 percent), farmers ( 9.3 percent), livestock's raising farmers (3.3 percent), teachers (3.1 percent) and anglers (1.4 percent). The respondents were then posed with several questions related to the utilization of loans extended by both banks. First, when asked about the uses of loan and reasons for opening bank account, their answers are as follows: 30 percent uses their loan to set up own businesses; 34 percent for their spouse business purposes; and, 17.9 percent uses loan for various purposes like for own business purposes. Other uses of loan include for children education ( 6.2 percent), paying back previous loan ( 4.8 percent), buying fixed assets ( 4.5 percent), and other purposes 2.6 percent. As for the reasons given for doing transactions with the respective banks, there is no significant difference between the two. Specifically, 84.3 percent of the respondents have their accounts in the respective banks because of convenience payment method (26.7 percent) and duration of getting loan is shorter ( 57.6 percent). However, it is worth noting that more people choosing BRAC (with 65.2 percent) for duration of getting loan is shorter compared to Grameen Bank (with 59.3 percent).

Next, when asked in what way the banks helped them to rid themselves of poverty, the respondents' answers can be divided into two. First, more than half of the respondents benefited from the loan by way of investing it in income-generating projects. This accounted for 59.3 percent of them. Second, they used the loans to

${ }^{6}$ The English version of the questionnaire is available upon request.

${ }^{7}$ In Bangladesh, a person with HSC qualification can enter university. 
acquire additional asset, which accounts for 56.7 percent of the respondents. Meanwhile, if we make a comparison between the groups who have account in both banks and who have account only in a single bank, the results are as follow: In general, the respondents having accounts in both banks (53.7 percent of them) benefited from the loan by way of income-generating and the remaining through acquiring additional assets. Specifically, in the case of BRAC 55.6 percent respondents said that the loans had facilitated them to generate income, while the rest said the loans had enabled them to acquire additional assets. However, in the case of Grameen bank the ratio is more than the BRAC where 67.6 percent of the respondents said they benefitted from the loans for it enable them to generate income, while 68.7 percent responded that it helps to acquire additional asset. It is clear from the above findings that the respondents taking loans from any one of the banks, as opposed to two banks at the same time, were benefitting more in their attempts to generate income and acquire additional assets. In recent study,Osmani (2011) has found that microcredit raises the amount of asset in absolute value. Specifically, he found that when a comparison is made between the borrowers of microcredit and the non-borrowers, despite the fact the former started their life with fewer assets; by virtue of having access to microcredit they were able to accumulate the assets at a faster rate than the latter.

Another important finding of our study is that only a very small percentage of our respondents (13.1 percent) are getting money remitted from abroad, especially from their family members. Out of the sample more than half (62.5 percent) received it from Asia-Pacific, while from Middle-East (35.7 percent) and Africa (1.8 percent). In terms of country, Malaysia is the prime source (42.9 percent), followed by Dubai (32.1 percent) and then Singapore (19.6 percent). Other sources are Saudi Arabia, Libya and Qatar (5.4 percent), if lumped together. Further, the respondents were then asked about whether they faced problem to repay the loan. Overall, half of the respondents were doing well, i.e., without facing problem, while the remaining half did have, at least once. Institution wise, more BRAC members (53.4 percent) were facing problem, at least once, as compared with Grameen Bank members (40.6 percent). Respondents having account in both BRAC and Grameen Bank, approximately 57 percent of them faced problem at least once. Hence, subject to further investigation, we can conclude from the foregoing results that borrowing money from more than one bank may increase the occurrences of default rate. Our finding seems to be consistent with (Faruqee \& Khalily, 2011) whose study shows that the default rate from multiple borrowings varies from $40-60 \%$ in Bangladesh. A further probe into the reasons for unable to repay the loans, our result reveals the followings: One, for BRAC, members making losses in business comprises 30.1 percent of the respondents where 21.9 percent of them used the loan for purpose other than expanding their business such as using money to wed the children or buying land properties etc. Two, in the case of Grameen Bank, some 29.5 percent of the borrowers used the loan for purposes that were unrelated to business. Others include: due to natural calamity and business losses, which together accounted for 23 percent. Ailment among family members, accounted for the remaining 18 percent. As for those having account in both banks, ailment among family members (37.3 percent) and using loan for purposes unrelated to business activities (21.3 percent) were the most important reasons for failing to fulfill the obligation of paying loan to the respective financiers.

Next, on the question whether the amount of loan provided by BRAC and Grameen Bank was sufficient to subdue the poverty, the respondents answered it in an affirmative way. More than half of the respondents (67 percent) think that the amount of loan they received from both institutions was enough to improve their economic situation. However a significant portion (28.4 percent) declined to comment and a very small portion (4.6 percent) said the money they received was not enough to improve their situation. If we compare Grameen Bank and BRAC separately, more Grameen Bank clients (65.7 percent) think that it has improved their situation compare to BRAC users (62.9 percent). The subsequent question posed to our respondents was a hypothetical one. It was related to seeking their view if an Islamic microfinance were made available to them. More than half (70.6 percent) expressed positively and looked forward to doing transactions with such institution. Moreover, as the institution is associated with an interest-free loan, we also asked them about the possibility of enjoying interest-free loan. Majority of them (82.4 per cent) in favor of dealing with interestfree loan, and the remaining 17.6 percent of respondents have positive impression about interest-bearing loans. Finally, the respondents were asked to rank their overall satisfaction level for being a member of these two microfinance provider. 92.1 percent said they are at least satisfied (i.e., 54.5 percent highly satisfied, 15.5 percent satisfied and 22.1 percent slightly satisfied) compare to dissatisfied only 7.9 percent (i.e., 2.1 percent highly dissatisfied, 1.4 percent slightly dissatisfied and 4.3 dissatisfied). 
Reliability Analysis: A number of tests are employed to gauge the reliability of the study. Among them are: First, Inter-item Consistency Reliability. It is a test of consistency of respondent's answers to all the items under investigation. The most popular test of inter-item consistency reliability is the Cronbach's coefficient alpha, which is used for multi point-scaled items. The higher the score, the more reliable the generated scale is. Normally " 0.7 is the acceptable reliability coefficient but lower threshold is sometimes used in the literature. As can be seen from Table 1, the Reliability Statistics recorded a Cronbach's Alpha 0.815, implying that respondent's answers are very consistent and reliable.

Table 1: Reliability Statistics

\begin{tabular}{lcc}
\hline Cronbach's Alpha & $\begin{array}{l}\text { Cronbach's Alpha } \\
\text { Standardized Items }\end{array}$ & Based on Number of Items \\
\hline .815 & .823 & 11 \\
\hline
\end{tabular}

Meanwhile, to assess the dimensionality of responses about bank performance in terms of services and staffs, factor analysis was performed using the principal factor/component (PF) method, followed by the varimax rotation. Table 2 shows the result of the factor analysis test for the variables. The Kaiser-Meyer-Olkin (KMO) value which is a measure of sampling adequacy, was found to be 0.773 , exceeding 0.5 , suggesting that the factor analysis had proceeded correctly and that sample was adequate. The results of the Bartletts Test of Sphericity were also significant, i.e., 0.000 , implying that the factor analysis processes were correct and suitable for testing multidimensionality.

Table 2: KMO and Bartlett's Test

\begin{tabular}{lcc}
\hline Kaiser-Meyer-Olkin Measure of Sampling Adequacy & & $\mathbf{. 7 7 3}$ \\
\hline Bartlett's Test of Sphericity & Approx. Chi-Square & 14109.613 \\
& df & 55 \\
& Sig. & .000 \\
\hline
\end{tabular}

Degree of Relationship and Hypothesis Testing: An independent-samples t-test was conducted to compare the bank staff managements (presence of bank staff, responsiveness of bank staff, courtesy and friendliness of bank staff, helpfulness of bank staff to enquiries, knowledge of bank staff about their loan services, entrepreneurial ability of bank staff, monitoring ability of bank staff, frequency of visit by bank staff) and bank services (easy access of loan, ease of doing transaction and range of services offering) for BRAC and Grameen Bank clients. The independent-sample t-test examined if there is any statistically significant differences in the mean score for BRAC and Grameen Bank users. A P-value indicates the probability of getting a mean difference between the groups (BRAC and Grameen Bank) where the lower the p-value is signifies the more significant the difference between the groups.

Table 3: Independent t-test

\begin{tabular}{lcccc}
\hline Variables name & \multicolumn{2}{c}{ Mean } & t-value & p-value \\
\hline & BRAC & Grameen & & \\
& & Bank & & \\
Presence of Bank Staff & 4.5564 & 4.4067 & 1.775 & .196 \\
Bank Staff response quickly for walk in Services & 4.1805 & 3.7333 & 4.850 & .000 \\
Bank Staff courteous and friendly & 4.2707 & 3.7667 & 5.459 & .000 \\
Bank Staff helpful and Handle Enquiries well & 4.0977 & 3.5267 & 5.936 & .000 \\
Bank Staff knowledgeable about Loan Services & 4.0451 & 3.4600 & 6.155 & .012 \\
Bank Staff have enough entrepreneurial Knowledge & 4.0827 & 3.5400 & 5.818 & .000 \\
Bank Staff Monitoring business taken after getting loan & 3.6391 & 2.8000 & 6.404 & .527 \\
Easy Access to Loan & 4.7444 & 4.6533 & 1.260 & .008 \\
\hline & & & & \\
Ease of Doing transaction with this bank & 4.7143 & 4.6400 & 1.026 & .017 \\
This Bank Offers a wide range of Services & 4.4361 & 4.5200 & .387 & .351 \\
\hline
\end{tabular}


This study found that Grameen Bank users had statistically significant lower preference levels compare to BRAC users in terms of responsiveness of bank staffs, courtesy of bank staff, helpfulness and way of providing information of bank staff, knowledge of bank staff about loan services and entrepreneurship, easiness of getting loan and doing transactions. In other words, it implies that BRAC staffs are faster in responding to the needs of their clients than Grameen staffs. Specifically, BRAC staffs are proven to be more courteous and friendly towards the clients than Grameen bank staffs. Lastly, in terms of helpfulness and attending to the enquiries of the clients, BRAC staff is doing better than the Grameen bank staff. Providing loan services to the poor is one of the main objectives of BRAC and Grameen Bank, which essentially requires the staff to have sufficient knowledge about their products. As in the previous cases, BRAC staff is ahead of Grameen Bank staff where the former staff seems to have more entrepreneurial knowledge to help the borrowers than the latter staff. It is worth noting here that having entrepreneurial knowledge is very important for microfinance banking because it helps the poor people on how to utilize the money in gainful ways. It has been argued that for an application of loan to get approval from the conventional bank it has to undergo a long screening process $^{8}$. Although microfinance institutions are targeting the poor people, the procedure or screening process is no better than the conventional banks. However, given BRAC and Grameen Bank, the poor seems to prefer opting for the former as getting loan from it is generally said to be easy and smooth. The result may imply that BRAC is more efficient in terms of time taken for an application to get approval from the date when the application is received to the date when it is approved. There was no significant difference in scores for BRAC and Grameen Bank users in terms of the presence of bank staffs and wideness of products servicing. This result indicates that the users of both banks are getting benefit by the presence of BRAC and Grameen Bank staff. Specifically, when a question related to this issue was posed, more than half of the respondents (56.4 percent) expressed a highest degree of satisfaction (very good) with the services extended by BRAC and Grameen Bank.

\section{Conclusion}

From our study it seems that the poor are the direct beneficiary of the existing micro-finance institutions in Bangladesh, namely Grameen Bank and BRAC. However, some of them, especially those who have accounts in both banks are having problem to repay the loans. Therefore, a mechanism has to be devised to limit each person to enjoy one loan at a time. In addition, it is also worth mentioning here that a high percentage of the poor in Bangladesh is looking forward to making loans from interest-free banks. Another important finding of ours is that the services rendered by both micro-financers to the poor are still no better than the conventional banks. In fact, more than 50.0 per cent of the respondents have shown their dissatisfaction with the services extended to them. To address this problem, it is highly recommended for both micro financers to improve their services by making it mandatory for their staff to undergo relevant training programs.

\section{References}

Adams, D. W. \& Von Pischke, J. (1992). Microenterprise credit programs: Déjà vu. World Development, 20(10), 1463-1470.

Buckley, G. (1997). Microfinance in Africa: Is it either the problem or the solution? World Development, 25(7), 1081-1093.

Faruqee, R. \& Khalily, B. (2011). Multiple Borrowing by MFI Clients: Current Status and Implications for Fututre of Microfinance. Dhaka: Institute of Microfinance (InM).

Harper, M. (2003). Microfinance: evolution, achievements and challenges, ITDG.

Hossain, M. (1988). Credit for alleviation of rural poverty: The Grameen Bank in Bangladesh, International Food Policy Research Institute Washington, DC.

Hulme, D. (2000). Impact assessment methodologies for microfinance: theory, experience and better practice. World Development, 28(1), 79-98.

\footnotetext{
${ }^{8}$ Once a borrower's application is taken, a loan officer will look over his/her credit reports, the amount of available collateral, and his/her income. The loan officer will figure out if any additional documentation is required, such as personal financial statements. After his/her loan package is presented to the decision makers, the processor will give you a letter of intent or term sheet. The reason for doing this is to reduce the risk of bad loans.
} 
Maes, J. P. \& Reed, L. R. (2012). State of the microcredit summit campaign report 2012. Microcredit Summit Campaign: Washington, DC.

Montgomery, H. \& Weiss, J. (2004). Great expectations: Microfinance and poverty reduction in Asia and Latin America, Asian Development Bank Institute.

Morduch, J. (1999). The microfinance promise. Journal of economic Literature, 37(4), 1569-1614.

Olivares-Polanco, F. (2005). Commercializing microfinance and deepening outreach? Empirical evidence from Latin America. Journal of Microfinance/ESR Review, 7(2), 47-69.

Osmani, S. (2011). Asset Accumulation and Poverty Dynamics in Rural Bangladesh: The Role of Microcredit, Working Paper. Dhaka: Institute of Microfinance.

Schuler, S. R. \& Hashemi, G. (1997). The influence of women's changing roles and status in Bangladesh's fertility transition: evidence from a study of credit programs and contraceptive use. World Development, 25(4) 563-575.

Shahidur, R. (1998). Fighting Poverty with Micro Credit: Experience in Bangladesh, University Press Limited, Dhaka.

Yunus, M. (2003). Banker to the Poor: Micro-Lending and the Battle Against World Poverty PublicAffairs, New York, 2003, ISBN 978-1-58648-198-8.

Web link

http://www.brac.net/, http://www.bangladesh-bank.org/, http://www.bids.org.bd/

http://www.grameen.com/, http://www.inm.org.bd/, http://www.mixmarket.org/

http://www.mra.gov.bd/, http://www.worldbank.org/, MRA-MIS databases.

\section{Appendix 1:}

\section{Demography of Respondents}

\begin{tabular}{lrr}
\hline & Frequency & Percent \\
\hline Name of District & & \\
Jessore & 223 & 53.1 \\
Jinaidaho & 97 & 23.1 \\
Satkhira & 50 & 11.9 \\
Bagerhat & 50 & 11.9 \\
Gender & & \\
Male & 102 & 24.3 \\
Female & 318 & 75.7 \\
Religion & & \\
Islam & 335 & 79.8 \\
Hindu & 78 & 18.6 \\
Christian & 7 & 1.7 \\
Marital Status & & .7 \\
Single & 3 & 96.7 \\
Married & 404 & .7 \\
Divorced & 3 & 1.9 \\
Widow & 8 & \\
Academic Qualifications & & 32.9 \\
Primary & 137 & 26.1 \\
Grade Eight & 109 & 20.4 \\
SSC & 85 & .5 \\
HSC & 2 & 20.1 \\
Vocational/Diploma & 84 & 60.9 \\
Occupation & & \\
Housewife & 255 & \\
& & \\
& &
\end{tabular}




$\begin{array}{lrr}\text { Farmer } & 39 & 9.3 \\ \text { Fishing } & 6 & 1.4 \\ \text { Livestock } & 14 & 3.3 \\ \text { Business } & 40 & 9.5 \\ \text { Tailor } & 48 & 11.5 \\ \text { Teacher } & 13 & 3.1 \\ \text { Other } & 4 & 1 \\ \text { Money Received from Abroad } & & \\ \text { Yes } & 56 & 13.3 \\ \text { No } & 364 & 86.7 \\ \text { Money Received from Abroad by Region } & & \\ \text { Asia-Pacific } & 35 & 62.5 \\ \text { Middle-East } & 20 & 35.7 \\ \text { Africa } & 1 & 1.8 \\ \text { Money Received from Abroad by Country } & & \\ \text { Malaysia } & 24 & 19.6 \\ \text { Singapore } & 11 & 32.9 \\ \text { Dubai } & 18 & 1.8 \\ \text { Saudi Arabia } & 1 & 1.8 \\ \text { Libya } & 1 & 1.8 \\ \text { Qatar } & 1 & \end{array}$

About Loan and Bank Services:

Use of Loan

Business Purpose for Own

Business Purpose for Spouse

Education Expenditure for Children

Expenditure for Buying Fixed Asset

To Pay other Previous Loan

Frequency

Percent

More than one of above mentioned reasons

126

30

143

34

26

6.2

19

4.5

20

4.8

Others Reasons

75

17.9

Reasons for Having Account in Banks

Low Interest Rate

11

2.6

Convenient Payment Method

23

5.5

Have Efficient Staff

112

26.7

Duration of getting Loan is shorter

21

242

5

More than one of above mentioned reasons

22

57.6

Use of Loan as Income Generating Purpose

Yes

246

5.2

No

59.3

No Comment

10.1

Sometimes

16.4

Acquire Additional Assets by Using Loan

Yes

59

14.2

No

237

56.7

Missing

181

43.3

Problem Faced Paying Loan (Overall)

Yes

11.2

No

210

50

Sometimes

163

38.8 
Problem Faced Paying Loan (BRAC)

Yes

11.9

No

Sometimes

56

46.7

Problem Faced Paying Loan (Grameen Bank)

41.5

Yes

No

Sometimes

Problem Faced Paying Loan (Have account both bank)

Yes

Sometimes

60

Reasons for Default to Pay Loan (BRAC)

Loss in Business

30.1

Use for another Purpose

Terms and Condition of Bank

Accident in family

9.6

Health Problem

5.5

Natural Calamity

5.5

More than one of above mention reasons

24.7

Reasons for Default to Pay Loan (Grameen Bank)

Loss in Business

9.8

Use for another Purpose

Terms and Condition of Bank

Accident in family

Health Problem

11.5

Natural Calamity

More than one of above mention reasons

Reasons Default to Pay Loan (Have Account in both Bank)

13.3

Loss in Business

Use for another Purpose

Terms and Condition of Bank

Accident in family

Natural Calamity

10.7

More than one of above mention reasons

Sufficiency of Loan Amount to Rid of Poverty

Yes

No

No Comment

Perception on Interest-free/Islamic Microfinance

Yes

No

No Comment

Missing Value

Level of satisfaction with the Overall Service Provided by Banks

Highly Dissatisfied

Slightly Dissatisfied

Dissatisfied

Slightly Satisfied 